\title{
Harvard officials in struggle against union representation
}

\section{Boston}

HARVARD University officials have challenged a vote held earlier this year that would make AFSCME (American Federation of State, County and Municipal Employees) the official bargaining unit for its approximately 4,000 clerical and technical workers. The National Labor Relations Board is expected to make a decision later this year in what has become a bitter labour struggle.

Harvard officials, who have consistently opposed the union, claim that union organizers violated the letter of labour law by the way they kept track of who had voted in the union plebiscite. The administration's complaint has narrowed from an earlier claim that union organizers coerced and intimidated voters into endorsement of the union.

On 17 May, with 93 per cent of the workers casting ballots, clerical and technical staff at Harvard voted in favour of the union by a margin of 44 votes. Remarkably, those 44 votes represented the largest margin ever won by a union at a private university in the United States.

The fight for union representation has focused on issues of self-representation and participation. The union made much of the high turnover of workers at the university, which ranges between departments from 25 per cent to 40 per cent. Rallying under the slogan "we can't eat prestige", the union organizers have been stressing not only the standard union issues of economic security, but also those of job satisfaction.

Some campus scientists have echoed the university's position against the union because they fear losing the flexibility to dismiss technicians whose work is unacceptable. Administration officials argued in a well funded campaign that a union would hurt university policy of merit-based pay in favour of promotion based on seniority and other criteria. University President Derek C. Bok has received special attention for his outspoken opposition to the union, which represents a shift from his well known former defence of pro-labour positions.

Union representatives acknowledge that salaries at Harvard tend to be higher overall than those at many other universities, and concede that the university has tended to be an 'average' employer in terms of wages and benefits. But chief organizer Kristine Rondeau says the university's recent claims of unfairness in the vote amount to stonewalling. She says that Harvard's position since the vote indicates that the university wants "to crush the union", saying that it is "willing to do almost anything to achieve that goal".

Robert Scott, university vice-president for finance, defends Harvard's complaints. "Our position is that it is not in the best interest of Harvard, or of the people who work here, to endorse the union", he says, "but it is their choice." He says that if the labour board, in its decision expected before the end of the year, finds the election to have been fair, then Harvard will willingly work with the union. But the issue may not be resolved, as neither Scott nor Rondeau rules out the possibility of an appeal against the decision.

Seth Shulman

\section{Dark horse in superconductor patent race}

\section{Tokyo}

A NEW competitor has entered the field in the complex international race to win patent rights to high-temperature superconductors. Last week, the newsletter Nikkei Superconductors revealed that Professor Kazuo Fueki, formerly of Tokyo University, filed a patent application for lanthanum-based superconductors on 22 December 1986, long before more famous contenders at IBM, AT\&T and Houston University.

Fueki says his patent application has been filed in the United States as well as in Japan and is for lanthanum-strontium and lanthanum-calcium copper oxides. $\mathrm{He}$ and his colleagues at Tokyo University made them by substituting strontium and calcium for barium in the material described in Bednorz and Muller's Nobel prize-winning work. The patent applica- tion also describes the crystal structure of the lanthanum-based superconductors.

As the patent is only for lanthanumbased compounds, it may be of little commercial value. But it seems certain to complicate the struggle for patent rights to the more valuable yttrium-based superconductors (see Nature 335, 4; 1988).

AT\&T and Paul Chu's group at Houston University are attempting to string together patent applications for yttrium- and lanthanum-based materials and date them from early January 1987 , when they filed patent applications for the lanthanum-based materials. Although these early patent applications allow for the possibility of yttrium substitution, patents were not filed specifically for yttriumbased superconductors until after the materials were discovered by Chu's group in late January 1987. David Swinbanks

\section{First scientific fraud conviction}

\section{Washington}

IN THE first criminal conviction for scientific fraud to come before a US court, a 36year old psychologist last week pleaded guilty to falsifying data that he presented to the federal agency funding his research.

The psychologist, Stephen Breuning, was working at the University of Pittsburgh when doubts were first raised about his research on the treatment of hyperactivity in mentally retarded children. Until recently he was assistant director at the Polk Center, a Pennsylvania state institution for the mentally retarded. $\mathrm{He}$ now faces a possible fine of $\$ 10,000$ and five years in prison on each of two charges after pleading guilty to making false statements to a federal agency at a court in Baltimore, Maryland.

The case is particularly serious because Breuning's research had a rapid impact on the choice of drugs used to treat certain behavioural disorders in mentally retarded children. As Robert Sprague, his accuser, put it, "the issue of scientific fraud in research on psychotropic medications

is not an academic game, but directly influences the lives and welfare of tens of thousands of mentally retarded people".

Sprague is a professor at the University of Illinois at Urbana-Champaign and an expert in the study of hyperactive and mentally retarded children. but despite the potential seriousness of the case, he had great difficulty in getting anyone to listen to his accusations. He first suspected that something was wrong with Breuning's work when he visited his laboratory in 1983 and noted an impossibly perfect level of agreement in independently judged behavioural scores. Later in the year, he wrote to the National Institute of Mental Health (NIMH) detailing his observations and pointing out that it was impossible to do the number of experiments claimed by Breuning in the time allotted for them. The complaints were passed to the University of Pittsburgh and Breuning apparently admitted that some statements concerning earlier work were false. But no investigation was made by the university of Breuning's work at Pittsburgh.

Three years after writing his first letter Sprague became "thoroughly disgusted" with the lack of action by NIMH and contacted Science magazine. Shortly after an article appeared there, NIMH issued a draft report. A final report followed four months later and stated that "Breuning knowingly, wilfully and repeatedly engaged in misleading and deceptive practices". Breuning will be sentenced in early November, close to five years from the time Sprague first wrote to NIMH.

Alun Anderson 